\title{
Estimating the Nature of Relationship of Entrepreneurship and Business Confidence on Youth Unemployment in the Philippines
}

\author{
Aileen L. CAMBA ${ }^{1}$
}

Received: June 04, 2020 Revised: June 14, 2020 Accepted: July 09, 2020

\begin{abstract}
This study estimates the nature of the relationship of entrepreneurship and business confidence on youth unemployment in the Philippines over the 2001-2017 period. The paper employed a range of cointegrating regression models, namely, autoregressive distributed lag (ARDL) bounds testing approach, Johansen-Juselius (JJ) and Engle-Granger (EG) cointegration models, dynamic OLS, fully modified OLS, and canonical cointegrating regression (CCR) estimation techniques. The Granger causality based on error correction model (ECM) was also performed to determine the causal link of entrepreneurship and business confidence on youth unemployment. The ARDL bounds testing approach, Johansen-Juselius (JJ) and Engle-Granger (EG) cointegration models confirmed the existence of long-run equilibrium relationship of entrepreneurship and business confidence on youth unemployment. The long-run coefficients from JJ and dynamic OLS show significant long-run and positive relationship of entrepreneurship and business confidence on youth unemployment. While results of the long-run coefficients from fully modified OLS and canonical cointegrating regression (CCR) found that only entrepreneurship has significant and positive relationship with youth unemployment in the long-run. The Granger causality based on error correction model (ECM) estimates show evidence of long-run causal relationship of entrepreneurship and business confidence on youth unemployment. In the short-run, increases in entrepreneurship and business confidence causes youth unemployment to decrease.
\end{abstract}

Keywords: Business Confidence, Canonical Cointegrating Regression, Dynamic OLS, Fully Modified OLS, Entrepreneurship, Youth Unemployment

JEL Classification Code: J6, J7, J64, M2

\section{Introduction}

While the labor force grows continuously, with an increasing proportion of young people, employment generation lagged to absorb labor market entrants. As a result, the youths are especially affected by unemployment making it a critical socio-economic problem in the Philippines. Moreover, young people are more likely to be employed in

${ }^{1}$ First Author and Corresponding Author. Associate Professor IV, Department of Economics, College of Social Sciences and Development, Polytechnic University of the Philippines, Philippines [Postal Address: Bgry. Kaunlaran, Quezon City, Metro Manila, 1111, Philippines] Email: alcamba@pup.edu.ph

(C) Copyright: The Author(s)

This is an Open Access article distributed under the terms of the Creative Commons Attribution Non-Commercial License (http://Creativecommons.org/licenses/by-nc/4.0/) which permits unrestricted noncommercial use, distribution, and reproduction in any medium, provided the original work is properly cited. jobs of low quality, underemployed, working long hours for low wages, engaged in dangerous work or receive only short term and/or informal employment arrangements (O’Higgins, 2003; Haftendorn \& Salzano, 2004). The unemployment situation of young people reflects the failure to make use of labor and available human capital to foster economic growth and global competitiveness (Chulanova et al. 2019) as they are not being used to their full potential (Šileika et al. 2004; Sy, 2013).

Cultures that value and reward entrepreneurial qualities (i.e., creativity and curiosity, motivation by success, willingness to take risks, ability to cooperate, identification of opportunities, and ability to be innovative and tolerate uncertainty) promotes development and lead to essential innovations (Herbig \& Miller, 1992; Lee \& Kim, 2019). Thus, entrepreneurship and business confidence can have significant impact on youth unemployment. A significant drop in entrepreneurship and business confidence can slow 
down economic activities leading to poor economic growth and recession, which can give rise to higher unemployment. Few investment projects mean potential layoff and freeze of hiring leading to a higher unemployment rate (Leve \& Kapingura, 2019; Bernanke, 1983).

The relationship of entrepreneurship and business confidence on youth unemployment has been covered with ambiguity in the case of the Philippines. This study provided an empirical evidence about the nature of relationship of entrepreneurship and business confidence on youth unemployment in the Philippines for the 20012017 period employing a range of cointegrating regression models.

\section{Theoretical Foundation}

\subsection{Schumpeter Effect: Entrepreneurship- Unemployment Link}

Schumpeter's (1934) theory of the business cycle does demonstrate clearly how unemployment can be reduced. Innovation, which creates more jobs, is the basic force in decreasing unemployment. When entrepreneurs innovate they increase investments to materialize those innovations. Thus, according to the Schumpeter Effect, there is an inverse proportional relationship between the entrepreneurship and unemployment. That is, as entrepreneurial activity increases, unemployment decreases.

\subsection{Animal Spirit: Business Confidence- Unemployment Link}

John Maynard Keynes (1936) understood very well that, in times of economic disturbance, irrational thoughts might influence people as they pursue their financial self-interests. The animal spirit, according to Keynes, is how people arrive at financial decisions in times of economic uncertainty. Animal spirits represent the emotions of confidence, hope, fear, and pessimism that can affect business decision making. If spirits are low, then confidence levels will be low, if spirits are high, confidence among participants in the economy will be high. Rising business confidence reflects positive economic sentiments, which lead to more hiring. If business confidence is shaken (i.e., political instability, peace and order situation, trade barriers, tax reforms, health pandemic, etc.) businesses are unwilling to take on new risk. In a broad sense, damage to morale that results to job losses and persistent unemployment in the overall economy. Businesses struggling to preserve their existence will inadvertently contribute to a vicious cycle of rising unemployment. Theoretically, rising business confidence reduces unemployment.

\section{Literature Review}

\subsection{Tendency Towards Entrepreneurship}

Hayton et al. (2002) model of how culture is associated with entrepreneurship emphasized that enterprise culture, institutional context, policy framework, outreach of the social network, education and skills level, enterprise promotion, strength of the economy and its sectors influence the labor market and the entrepreneurship situation in a country. Using the Community Based Monitor System (CBMS) survey on Accelerated Poverty Profiling among member schools of De La Salle Philippines, Gozun and Rivera (2017) showed that education increases the wage-earning capacity of young people, thus, increasing their tendencies toward employment more than entrepreneurship. In the long run, as the wealth of young people accumulates through other streams, they tend to give high consideration toward being an entrepreneur than being employed. The study by Leve and Kapingura (2019) empirically assessed the entrepreneurial interest among male and female undergraduate and postgraduate students in the Eastern Cape Province of South Africa, using the survey research design, and a structured validated questionnaire. The results revealed that perceived time and entrepreneurial skills constraints jointly influenced entrepreneurship interest of the students. Policies must be geared in promoting the spirit of entrepreneurship among young people to help reduce joblessness. Lee and Kim (2019) analyze how the career orientation factors of startup entrepreneurs affect entrepreneurial satisfaction as well as business sustainability. The results demonstrated that the entrepreneurial creativity and managerial competence of the members of a startup can play an important role within entrepreneurial satisfaction and business sustainability. In order to improve entrepreneurial satisfaction and achieve business sustainability, it is important for startups to consider the creativity and business management competences of entrepreneurs.

The study by Dahliah et al. (2020) analyzes the strategy of determining economic development planning on SME improvement in Indonesia. Accordingly, to strengthen regional development of SMEs, government strategy must include industrial control, community cooperatives and infrastructure improvements, strategies to improve institutional performance work capacity and work ethic, cultivation of potential technological development and improvement of the quality of the environment. Satpayeva et al. (2020) analyzed women's entrepreneurship in Kazakhstan. They observed increasing contribution of women in social-economic development, women's entrepreneurial activity is increasing, and the number of enterprises headed by women is growing. Surprisingly, women entrepreneurship in Kazakhstan thrives in the service sector. Thus, strategic actions require priority 
attention: 1) export support for women entrepreneurs, 2) development of the high-tech sector of women's business, 3) development of a system of social support for motherhood, 4) development of business education among girls, 5) development of infrastructure to support women's entrepreneurship, 6) development of a system of indicators for monitoring, and 7) development of women's entrepreneurship. Sanyal et al. (2020) analyses the challenges facing SMEs in Oman in their quest for internationalization based on the OECD Model of Internationalization. It was found that finance availability was the most significant predictor of internationalization followed by market access and business environment. Government intervention for easy lines of credit and relax custom duties to support SME exporters.

\subsection{Basic Skills and Job-skills Mismatch}

The poor communication skills and lack of other specialist skills of young people when applying for a job is an obstacle. This implies that the increased participation of young people in education and training has not necessarily led to an increase in skills. Further exacerbating this lack of overall skill level is the presence of a job-skills mismatch, which, despite having attained higher educational qualifications, many young people end up being unemployed (Evangelista \& Ortiz, 2009). Canlas and Pardalis (2009) noted a serious job-skills mismatch between the demands of the workplace and the skills being taught in the educational institutions. According to Esguerra (2009) a mismatch occurs 1) when the educational system fails to deliver the minimum capabilities that are needed by the economy, 2) due to market bias among firms who will tend to hire older and more experienced workers, 3) locational problems of supply and demand for skills, 4) rules on the minimum wage and regularization of employment - creating market inflexibility, and 5) involuntary unemployment may occur despite investment into education and training by governments. Pernia and Herrin (2003) argued that the oversupply of labor was the result of the Philippines' high fertility rate, as well as the failure of the economy to generate enough employment due to a structural problem, more specifically, a job-skills mismatch in the labor market. Canlas et al. (2006) noted the dismal growth of labor productivity and rightly argued that the country is not doing well both on labor-capital ratio and total factor productivity (TFP), which pertain to the efficient use of labor and capital. International studies conducted by Trehan (2001), Storey (1991), Evans and Leighton (1990) explained that a mismatch between demand and supply of labor may be caused by expansionary monetary and fiscal policies and powerful trade unions. For instance, unions setting higher wages than market wages, generates unemployment.

\subsection{Concerns of Policy-Making}

Canlas and Pardalis (2009) mentioned a number concerns to be addressed: 1) youth unemployment in the Philippines continues to increase despite of substantial economic growth, 2) a significant proportion of the young female population has been excluded from the labor force, 3) the employment situation of many young people is mostly in low-paid jobs, 4) a significant number of the unemployed did not even look for work, 5) the incidence and rate of unemployment increase as the level of educational attainment gets higher, and 6) migration of young people overseas will continue. Canlas and Pardalis (2009) also noted that the majority of young people would rather work abroad than in the Philippines. This does not augur well for the future of the Philippines unless longer-term industrial policies can be implemented that would result in greater employment opportunities at home, which would attract these people to stay or return with added skills.

\section{Research Methodology}

Youth unemployment can be expressed as a function of entrepreneurship and business confidence as follows: $Y U=f(E N T R E P, B C)$, where ENTREP and BC denote entrepreneurship and business confidence that can influence youth unemployment (YU), respectively. Converting the functional equation into its linear form:

$$
Y U_{t}=\alpha_{0}+\alpha_{1} \text { ENTREP }_{t}+\alpha_{2} B C_{t}+e_{t}
$$
term.

where $\alpha_{0}, \alpha_{1}$ and $\alpha_{2}$ are parameter estimates, $e_{\mathrm{t}}$ is the error

The dependent variable youth unemployment is the percent of young people unemployed to the total labor force ages 15-24 accessed from the World Development Indicators by the World Bank. The independent variables used in this study are entrepreneurship and business confidence. Entrepreneurship is the rate of self-employed in total employment, which is the generally-accepted indicator of entrepreneurship (Thurik et al. 2007; Baptista \& Thurik, 2007). Data for this variable was taken from Philippine Statistics Authority (PSA). Data on business confidence was gathered from the Business Expectation Survey of the Bangko Sentral ng Pilipinas (BSP). The time span covers the 2001-2017 period.

\subsection{Unit Root Tests}

In order to analyze the order of integration, it is necessary to test whether the variables, YU, ENTREP and BC, are stationary using augmented Dickey-Fuller (ADF) unit root test (Dickey \& Fuller, 1979) and Phillips-Perron (PP) unit root 
test (Phillips \& Perron, 1988). If the variables are integrated processes, the empirical analysis is going to rely on the estimation of a VAR model (i.e., in first differences):

$$
\begin{aligned}
& \Delta z_{t}=\delta_{0}+\delta_{1} Z_{t-1}+\sum_{i=1}^{k} \alpha_{i} \Delta Z_{t-i}+\mu_{t} \\
& \Delta z_{t}=\delta_{0}+\delta_{1} t+\delta_{2} Z_{t-1}+\sum_{i=1}^{k} \alpha_{i} \Delta Z_{t-i}+\mu_{t}
\end{aligned}
$$

where $t$ and $k$ refers to the time and number of lags. $\Delta Z_{\mathrm{t}-\mathrm{i}}$ refers to the first difference of the variable with $k$ lags. The term $\mu_{t}$ adjusts the errors of autocorrelation. The parameters $\alpha_{i}, \delta_{0}, \delta_{1}$ and $\delta_{2}$ are estimated.

\subsection{Cointegration Models}

\subsubsection{Autoregressive Distributed Lag (ARDL) Bounds Testing Model}

This study employed the autoregressive distributed lag (ARDL) bounds testing approach developed by Pesaran et al. (2001) to analyze the long-run relationship of entrepreneurship and business confidence on youth unemployment. The unrestricted error correction ARDL model for equation (1) is presented as follows:

$$
\begin{aligned}
\Delta Y U_{t}= & \propto_{0}+\beta_{1} Y U_{t-1}+\beta_{2} \text { ENTREP }_{t-1}+\beta_{3} B C_{t-1} \\
& +\sum_{i=1}^{p} \delta_{1 i} \Delta Y U_{t-i}+\sum_{i=0}^{p} \delta_{2 i} \Delta E N T R E P_{t-i} \\
& +\sum_{i=0}^{p} \delta_{3 i} \Delta B C_{t-i}+\varepsilon_{t}
\end{aligned}
$$

where $\Delta$ is the difference operator, $\mathrm{p}$ is the lag length, $\alpha$, $\beta$ and $\delta$ are parameter estimates, and $\varepsilon_{\mathrm{t}}$ is the random error term.

\subsubsection{Johansen and Juselius Cointegration Model}

The standard Johansen-Juselius (JJ) cointegration technique was also performed. The equation for the $\mathrm{JJ}$ test in a VAR model can be expressed as follows:

$$
\begin{aligned}
\Delta Z_{t}=\varphi & +\Gamma_{1} \Delta Z_{t-1}+\Gamma_{2} \Delta Z_{t-2}+\ldots \\
& +\Gamma_{P-1} \Delta Z_{t-P}+\Gamma Z_{t-1}+\mu_{t}
\end{aligned}
$$

where $\varphi$ is the vector (Px1) of constant terms, $\Delta$ is the difference operator, $Z_{t}$ is the Px1 vector of variables in the model, $\Gamma$ is the coefficient matrix, $\mu_{t}$ is the vector (Px1) of disturbance term and $\Pi$ is the (PxP) coefficients matrix. The matrix of $\Pi$ shows the long-run relationship between $Z_{t}$ variables while the rank of $\Pi$ means the number of linearly dependent and stationary linear combination of variables. As proposed by Johansen (1998) and Johansen and Juselius
(1990) there are two test statistics for testing the number of co-integrating vectors in the VAR model, trace test and maximum-eigen value test.

\subsubsection{Engle and Granger (EG) Residual-based Cointegration Model}

The Engle and Granger (1987) residual-based cointegration was also administered. Equation (1) was estimated using OLS and tested the residual series for stationarity using ADF test. The test statistic was compared with MacKinnon (2010) critical values. If the residuals of estimated model are stationary, then equation (1) is a longrun model. The ADF t-statistic was estimated as follows:

$$
\Delta \widehat{e}_{t}=\rho \widehat{e}_{t-1}+\sum_{j=1}^{k} \beta_{j} \Delta \widehat{e}_{t-j}+V_{t}
$$

\subsubsection{Fully-modified Ordinary Least Squares (FMOLS) Cointegration Model}

Fully-modified OLS is a semi-parametric approach to estimate long-run parameters. It gives consistent parameters even in small sample size and overcomes the problems of endogeneity, serial correlation, omitted variable bias, measurement errors and allows for the heterogeneity in the long-run parameters. The FMOLS estimator can be obtained as follows:

$$
\hat{O}_{F M E}=\left(\sum_{t=1}^{T} Z_{t} Z_{t}^{\prime}\right)^{-1}\left(\sum_{t-1}^{T} Z_{t} Y_{t}^{+}-T\left[\lambda_{12_{0}^{\prime}}^{+}\right]\right)
$$

where $Y_{t}^{+}$and $\lambda_{12}^{+}$terms correct the endogeneity and serial correlation.

\subsubsection{Dynamic Ordinary Least Squares (DOLS) Cointegration Model}

The dynamic OLS adopts a parametric approach in estimating long-run relationship in which the variables are integrated in different order, but still cointegrated (Kurozumi \& Hayakawa, 2009; Masih \& Masih, 1996). The DOLS estimators, which are unbiased and asymptotically efficient can be obtained from least-squares estimates:

$$
y_{t}=a+b X_{t}+\sum_{i=-k}^{i=k} \varnothing_{i} \Delta X_{t+1}+\epsilon_{t}
$$

where $\boldsymbol{b}$ as the long-run elasticity. The term Ø's are the coefficients of leads and lags differences of I(1) regressors which are considered as nuisance parameters but they adjust for possible endogeneity, autocorrelation, and non-normal residuals. 


\subsubsection{Canonical Cointegrating Regression (CCR) Model}

The CCR method can be used for testing cointegrating vectors in a model with integrated processes of I(1). This method, a single equation regression, can be applied in multivariate regression without modification and losing its efficiency, thus the CCR estimator is obtained as:

$$
\hat{O}_{C C R}=\left(\sum_{t=1}^{T} Z_{t}^{*} Z_{t}^{* 1}\right)^{-1} \sum_{t=1}^{T} Z_{t}^{*} Y_{t}^{*}
$$

The Granger causality based on error correction model (ECM) was also performed to determine the causal link of entrepreneurship and business confidence on youth unemployment.

\section{Results and Discussion}

The ability of young people to engage in productive activities has both social and economic consequences for an economy. However, the intensity of youth unemployment is quite prevalent and widespread. In the Philippines, young people aged 15-24 saw an average of 9.2506 percent for the period 2001-2017 (see Table 1). Table 1 also depicts the entrepreneurship data (i.e., self-employed) of the Philippines from 2001 to 2017 with an average of 44.7353 percent. Rising business confidence reflect positive economic prospects, which lead to more hiring. During the 2001-2017 period, business confidence averaged 28.2165 percent. Moreover, the Jarque-Bera statistics suggest, asymptotically, we do not reject the normality assumption.

\subsection{Unit Root Test Results}

The unit root test results were reported in Table 2. The ADF test results were statistically significant at 1 percent, 5 percent and 10 percent for both ENTREP and BC at levels $\mathrm{I}(0)$ and first difference $\mathrm{I}(1)$ signifying the absence of unit root. In the case of YU, ADF is not significant at $\mathrm{I}(0)$, that is, has a unit root or non-stationary at levels and must be tested at first difference I(1). At I(1), YU is stationary, signifying absence of unit root at order 1 . The PP test shows that YU and ENTREP are non-stationary at levels I(0) but they are stationary at their first difference I(1) at a 1 percent level of significance, hence the time series are integrated of order 1, I(1). The PP test of BC show stationarity at levels $\mathrm{I}(0)$ and first difference I(1) with significance at 1 percent and 5 percent levels. Overall, YU becomes I(1) after first differencing, and ENTREP and BC are integrated at $\mathrm{I}(0)$ and $\mathrm{I}(1)$.

Table 1: Descriptive Statistics

\begin{tabular}{|l|c|c|c|}
\hline & Youth Unemployment & Entrepreneurship & Business Confidence \\
\hline Mean & 9.2506 & 44.7353 & 28.2165 \\
\hline Maximum & 10.3300 & 50.7000 & 47.9000 \\
\hline Minimum & 7.4100 & 37.8000 & $(15.2000)$ \\
\hline Jarque-Bera & 3.1603 & 1.6038 & 1.9421 \\
\hline Probability & 0.2059 & 0.4485 & 0.3787 \\
\hline
\end{tabular}

Table 2: ADF and PP Unit Root Test Results

\begin{tabular}{|c|c|c|c|c|c|}
\hline \multirow[b]{2}{*}{ Variable } & \multicolumn{2}{|c|}{ Levels } & \multicolumn{2}{|c|}{ First Difference } & \multirow{2}{*}{$\begin{array}{l}\text { Order of } \\
\text { Integration }\end{array}$} \\
\hline & Constant & $\begin{array}{c}\text { Constant, Linear } \\
\text { Trend }\end{array}$ & Constant & $\begin{array}{c}\text { Constant, Linear } \\
\text { Trend } \\
\end{array}$ & \\
\hline \multicolumn{6}{|c|}{ Augmented Dickey-Fuller (ADF) } \\
\hline YU & -0.6814 & -1.1259 & $-4.5387^{* * *}$ & $-3.8934^{* *}$ & $\mathrm{I}(1)$ \\
\hline ENTREP & 0.1942 & $-5.5384^{* * *}$ & $-2.6669^{*}$ & $-4.6344^{* * *}$ & $\mathrm{I}(0), \mathrm{I}(1)$ \\
\hline $\mathrm{BC}$ & $-3.1807^{* *}$ & $-3.7492^{* *}$ & $-4.7275^{* * *}$ & $-4.6163^{* * *}$ & $\mathrm{I}(0), \mathrm{I}(1)$ \\
\hline \multicolumn{6}{|c|}{ Phillips-Perron (PP) } \\
\hline YU & -0.6814 & -0.9402 & $-4.5387^{* * *}$ & $-9.3599^{* * *}$ & $I(1)$ \\
\hline ENTREP & 1.3432 & -2.6525 & $-5.0390^{* * *}$ & $-4.9975^{\star * *}$ & $\mathrm{I}(1)$ \\
\hline $\mathrm{BC}$ & $-3.1932^{* *}$ & $-8.3083^{* * *}$ & $10.8487^{* * *}$ & $-10.2766^{* * *}$ & $\mathrm{I}(0), \mathrm{I}(1)$ \\
\hline
\end{tabular}



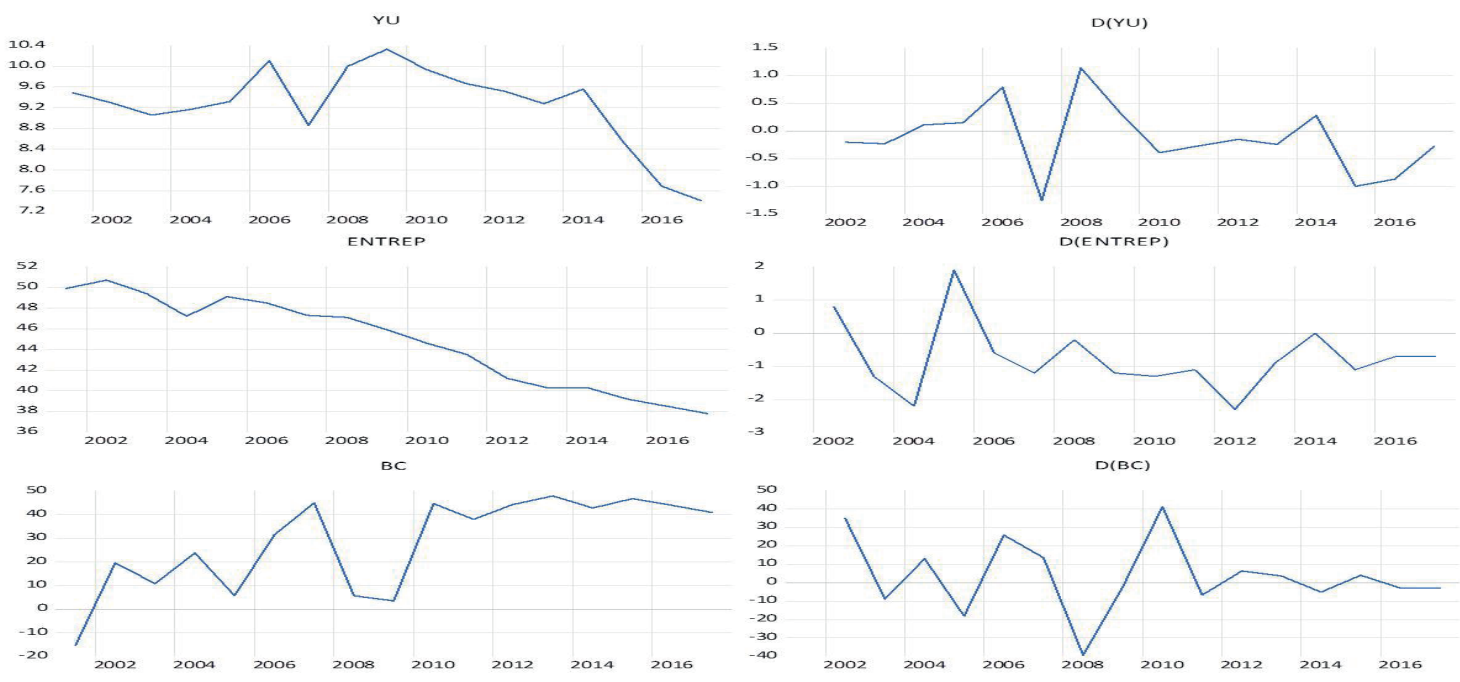

Figure 1: Nonstationary and Stationary Plots

Table 3: ARDL Bounds Testing Results

\begin{tabular}{|c|c|c|c|c|}
\hline Test Statistic & Value & Significance & $I(0)$ & I(1) \\
\hline \multirow{3}{*}{ F-statistic } & \multirow{3}{*}{4.9866} & $10 \%$ & 2.6300 & 3.3500 \\
\hline & & $5 \%$ & 3.1000 & 3.8700 \\
\hline & & $1 \%$ & 4.1300 & 5.0000 \\
\hline \multicolumn{5}{|c|}{ ARDL Long-run Coefficients } \\
\hline \multicolumn{2}{|c|}{ Variable } & Coefficient & t-Statistic & Prob. \\
\hline \multicolumn{2}{|l|}{ ENTREP } & 0.2238 & 1.1741 & 0.3612 \\
\hline \multicolumn{2}{|l|}{$\mathrm{BC}$} & 0.0268 & 0.9810 & 0.4300 \\
\hline \multicolumn{2}{|l|}{ C } & -2.3435 & -0.2430 & 0.8307 \\
\hline
\end{tabular}

In Figure 1, the nonstationarity and stationarity of the variables were presented. The nonstationary series $\mathrm{YU}$, ENTREP and $\mathrm{BC}$ were compared to their stationary series $\mathrm{D}(\mathrm{YU}), \mathrm{D}(\mathrm{ENTREP})$ and $\mathrm{D}(\mathrm{BC})$. The plots of the series YU, ENTREP and $\mathrm{BC}$ exhibit a trend suggesting nonstationarity. On the other hand, the plots of D(YU), D(ENTREP) and $\mathrm{D}(\mathrm{BC})$ shows pattern with no discernible upward nor downward trend, suggesting stationarity.

\subsection{Cointegration Models Test Results}

\subsubsection{Autoregressive Distributed Lag (ARDL) Bounds Testing Model}

The estimated ARDL model established the cointegration of entrepreneurship and business confidence on youth unemployment. As shown in Table 3, the F-statistic of 4.9866 is greater than the upper bound critical value of 3.8700 at 5 percent significance level. These results justify the long-run relationship of entrepreneurship and business confidence on youth unemployment. In the long run, entrepreneurship and business confidence have positive relationship with youth unemployment, but not statistically significant.

\subsubsection{Johansen and Juselius Cointegration Model}

The results of the Johansen and Juselius cointegration test confirmed the existence of long-run relationship of entrepreneurship and business confidence on youth unemployment from 2001 to 2017. Both the trace test and max-eigen test indicates 1 cointegrating equation at 0.05 level of significance.

The normalized cointegrating coefficients are reported in Table 5. According to the results, entrepreneurship and business confidence exhibit a positive and significant relationship with youth unemployment in the long run with 
Table 4: Johansen and Juselius Cointegration Results

\begin{tabular}{|c|c|c|c|c|c|c|}
\hline \multirow{2}{*}{$\begin{array}{l}\text { Hypothesized No. } \\
\text { of CE(s) }\end{array}$} & \multirow{2}{*}{$\begin{array}{l}\text { Trace } \\
\text { Statistic }\end{array}$} & \multicolumn{2}{|c|}{5 percent } & \multirow{2}{*}{$\begin{array}{c}\text { Max-Eigen } \\
\text { Statistic }\end{array}$} & \multicolumn{2}{|c|}{5 percent } \\
\hline & & Critical Value & Prob.** & & Critical Value & Prob. ${ }^{* *}$ \\
\hline None * & 36.9030 & 29.7971 & 0.0064 & 22.4157 & 21.1316 & 0.0328 \\
\hline At most 1 & 14.4873 & 15.4947 & 0.0705 & 14.0674 & 14.2646 & 0.0537 \\
\hline At most 2 & 0.4200 & 3.8415 & 0.5169 & 0.4200 & 3.8415 & 0.5169 \\
\hline
\end{tabular}

Table 5: Normalized Cointegrating Coefficients

\begin{tabular}{|l|c|c|}
\hline \multicolumn{1}{|c|}{$\mathbf{D}(\mathrm{YU})$} & D(ENTREP) & D(BC) \\
\hline 1 & $-1.1837^{* *}$ & $-0.1554^{* * *}$ \\
\hline t-statistic & 2.6950 & 5.3840 \\
\hline $\begin{array}{l}* * \text { indicates significance at the 1 percent level } \\
* * \text { indicates significance at the 5 percent level }\end{array}$ \\
\hline
\end{tabular}

Table 6: Engle and Granger Cointegration Results

\begin{tabular}{|c|c|c|c|}
\hline \multirow{3}{*}{\multicolumn{2}{|c|}{$\begin{array}{c}D(R E S I D) \text { has a } \\
\text { unit root }\end{array}$}} & \multicolumn{2}{|c|}{ ADF Test } \\
\hline & & \multirow{2}{*}{$\begin{array}{c}\text { t-Statistic } \\
-5.0152\end{array}$} & \multirow{2}{*}{$\begin{array}{l}\text { Prob. }^{*} \\
0.0030\end{array}$} \\
\hline & & & \\
\hline \multirow{3}{*}{ Test critical values: } & $1 \%$ level & \multicolumn{2}{|c|}{-4.2001} \\
\hline & $5 \%$ level & \multicolumn{2}{|c|}{-3.1754} \\
\hline & $10 \%$ level & \multicolumn{2}{|c|}{-2.7290} \\
\hline
\end{tabular}

level of significance at 5 percent and 1 percent, respectively. Thus, the first normalized cointegrating equation can be constructed as: $\mathrm{YU}=1.1837 \mathrm{ENTREP}+0.1554 \mathrm{BC}$.

\subsubsection{Engle and Granger (EG) Residual-based Cointegration Model}

Similarly, the Engle and Granger (EG) residual-based cointegration test indicates cointegration between the variables (see Table 6). This is due to the fact that estimated ADF and PP statistics of the residual after first differencing $\mathrm{D}$ (RESID) is stationary at 1 percent level. Hence, any deviation in the existing equilibrium relationship between $\mathrm{YU}, \mathrm{ENTREP}$ and $\mathrm{BC}$ are temporary and move together in the long run.

\subsubsection{FMOLS, DOLS and CCR Cointegration Models}

The FMOLS results in Table 7 reveal a statistically significant positive relationship of entrepreneurship on youth unemployment at 10 percent level of significance. Regarding business confidence, it has positive influence, but insignificant. Results of the DOLS estimation technique for cointegrating regression show statistically positive relationship of ENTREP and BC on YU at 5 percent and 10 percent levels, respectively. Thus, the nature of long-run relationship of entrepreneurship and business confidence on youth unemployment, is found to be positive and significant. In this case, entrepreneurship and business confidence leads to increases in youth unemployment, or more entrepreneurship and business confidence means higher youth unemployment. The CCR results reveal a statistically significant positive long-run relationship of entrepreneurship on youth unemployment at 10 percent level of significance. As for business confidence, it has positive influence, but insignificant.

In summary, the ARDL, JJ and EG cointegration models confirmed the existence of long-run equilibrium relationship of entrepreneurship and business confidence on youth unemployment. Results of the long-run coefficients from JJ and DOLS estimation techniques show significant long-run and positive relationship of entrepreneurship and business confidence on youth unemployment. While results of the long-run coefficients from FMOLS and CCR found that only entrepreneurship has significant and positive 
Table 7: FMOLS, DOLS and CCR Results

\begin{tabular}{|c|c|c|c|c|c|}
\hline Variable & Coefficient & t-stat. & Prob. & $\mathbf{R}^{2}$ & Adj. $\mathbf{R}^{2}$ \\
\hline \multicolumn{6}{|c|}{ Fully-modified Ordinary Least Squares } \\
\hline ENTREP & 0.1580 & 2.0303 & 0.0633 & \multirow{3}{*}{0.1557} & \multirow{3}{*}{0.0277} \\
\hline $\mathrm{BC}$ & 0.0180 & 0.8923 & 0.3884 & & \\
\hline C & 1.5057 & 0.3833 & 0.7077 & & \\
\hline \multicolumn{6}{|c|}{ Dynamic Ordinary Least Squares } \\
\hline ENTREP & 0.3342 & 3.1855 & 0.0244 & \multirow{3}{*}{0.7483} & \multirow{3}{*}{0.3455} \\
\hline $\mathrm{BC}$ & 0.0619 & 1.9973 & 0.1023 & & \\
\hline C & -8.2138 & -1.4538 & 0.2057 & & \\
\hline \multicolumn{6}{|c|}{ Canonical Cointegrating Regression } \\
\hline ENTREP & 0.1813 & 1.9864 & 0.0685 & \multirow{3}{*}{0.1286} & \multirow{3}{*}{-0.0055} \\
\hline $\mathrm{BC}$ & 0.0209 & 0.8938 & 0.3877 & & \\
\hline C & 0.4052 & 0.0876 & 0.9315 & & \\
\hline
\end{tabular}

Table 8: Granger Causality Based on Error Correction Estimates

\begin{tabular}{|l|c|c|c|}
\hline \multicolumn{1}{|c|}{ Variable } & Coefficient & t-stat. & Prob. \\
\hline Constant & -2.9567 & -6.2687 & 0.0245 \\
\hline $\mathrm{D}(\mathrm{ENTREP}(-1))$ & $-0.3090^{*}$ & -3.8952 & 0.0600 \\
\hline $\mathrm{D}(\mathrm{BC}(-1))$ & $-0.0230^{* *}$ & -5.0554 & 0.0370 \\
\hline $\mathrm{ECM}(-1)$ & $-1.2616^{* *}$ & -6.2535 & 0.0246 \\
\hline $\begin{array}{l}\text { R-squared }=0.9728 \text { Adjusted R-squared }=0.9116 \quad \text { F-statistic }=15.8979 \text { Prob. (F-statistic) }=0.0086 \mathrm{DW}=3.0750 \\
\text { Statistical significance: }{ }^{* * *}(1 \%),{ }^{* *}(5 \%) \text { and }{ }^{*}(10 \%)\end{array}$
\end{tabular}

relationship with youth unemployment in the long run. To this end, it is obvious that the nature long-run relationship of entrepreneurship and business confidence on youth unemployment in the Philippines is positive. This means that, in the case of the Philippines, an increase in entrepreneurial activities and business confidence leads to an increase in youth unemployment in the long run. The positive long-run relationship of entrepreneurship and business confidence on youth unemployment may be explained by the presence of job-skills mismatch in the Philippine labor market (Canlas \& Pardalis, 2009; Esguerra, 2009; Pernia \& Herrin, 2003; Trehan, 2001; Storey, 1991; Evans \& Leighton, 1990).

In view of the above cointegration results, Table 8 also presents the Granger causality based on ECM estimates. The results indicate that the lagged changes in entrepreneurship (D(ENTREP(-1)) and business confidence (D(BC(-1)) have inverse and statistically significant relationship on youth unemployment in the short-run at 10 percent and 5 percent levels, respectively. Therefore, in the short run, increases in entrepreneurship and business confidence causes youth unemployment to decrease (i.e., Schumpeter Effect and Keynes' Animal Spirit). The ECM(-1) $=-1.2616$ with p-value of 0.0246 means that any change in the present equilibrium level is a temporary phenomenon and will restore back to the long-run path. According to the magnitude of $\mathrm{ECM}_{\mathrm{t}-1}$ any deviation of the equilibrium will be corrected at the speed of 126.16 percent annually. The statistically significant error correction term shows evidence in support of long-run causal relationship from entrepreneurship and business confidence to youth unemployment. The CUSUM test and CUSUM of squares test (Figure 2) show that the estimated parameters are stable over the 2001-2017 period.

\section{Conclusions}

This study provided an empirical evidence about the nature of the relationship of entrepreneurship and business confidence on youth unemployment in the Philippines employing various cointegration models. The ARDL, JJ and EG cointegration models confirmed the existence of long-run equilibrium relationship of entrepreneurship and business confidence on youth unemployment. The long-run coefficients from JJ and DOLS estimation techniques show significant long-run and positive relationship of entrepreneurship and business confidence on youth unemployment. While results of the long-run coefficients from FMOLS and CCR found that only entrepreneurship has significant and positive relationship with youth unemployment in the long run. In the case of the Philippines, increases in entrepreneurial activities and business confidence leads to increases in youth 

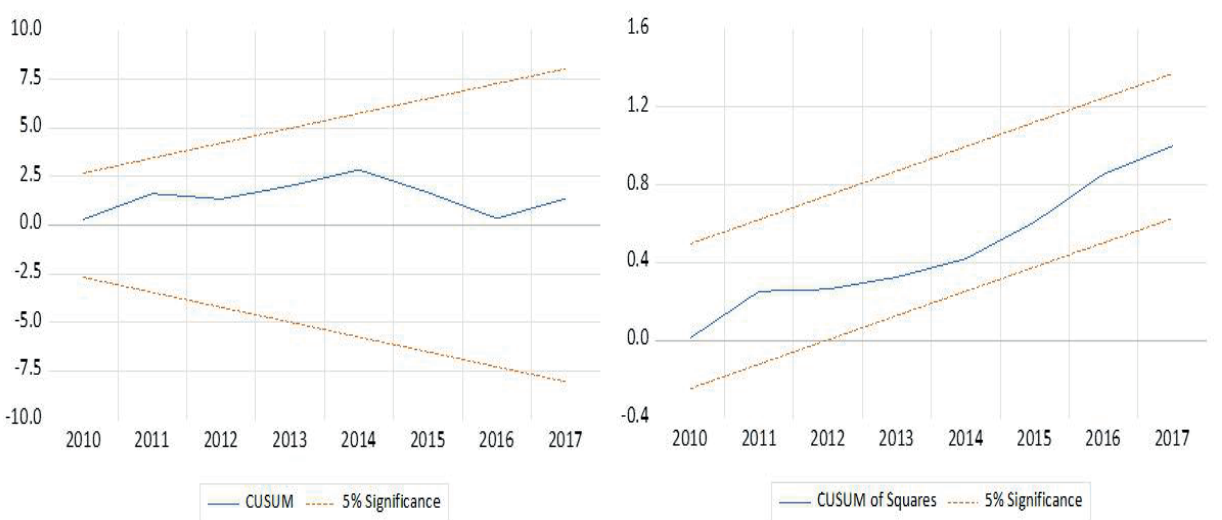

Figure 2: CUSUM and CUSUM of Squares Plots

unemployment in the long-run. The Granger causality based on error correction model show evidence of long-run causal relationship from entrepreneurship and business confidence to youth unemployment. In the short run, increases in entrepreneurship and business confidence causes youth unemployment to decrease.

Addressing youth unemployment requires both shortand long-term measures that involve increasing demand for labor, improving education and skills, and labor market policy priority programs and projects that improve the employability of the youths. Obviously, entrepreneurship is a viable option for young people because of their great creativity, dynamism and untapped talents, easy financial access and sharpening their entrepreneurial skills through training must be provided. Also, it is important to institute programs that comprehensively recognize the value of maintaining business confidence in the economy. Since there is the need to look at policies and interventions to maintain business confidence.

\section{References}

Baptista, R., \& Thurik, A. (2007). The relationship between entrepreneurship and unemployment: is Portugal an outlier? Technological Forecasting \& Social Change, 74, 75-89. https:// doi.org/10.1016/j.techfore.2006.04.003

Barsky, R. B., \& Sims, E. R. (2012). Information, animal spirits, and the meaning of innovations in consumer confidence. American Economic Review, 102(4), 1343-1377.

Bernanke, B. (1983). Irreversibility, uncertainty and cyclical investment. Quarterly Journal of Economics, 98, 85106. https://doi.org/10.2307/1885568

Blanchflower, D. G., \& Meyer, B. (1994). A longitudinal analysis of young entrepreneurs in Australia and the United States. Small Business Economics, 6(1), 1-20.

Canlas, L., \& Pardalis, R. (2009). Youth employment in the Philippines. ILO Asia-Pacific Working Paper Series, December.
Retrieved January 22, 2020, from: https:/www.ilo.org/ wcmsp5/groups/ public/---asia/---ro-bangkok/---ilo-manila/ documents/publication/wcms_142947.pdf

Chulanova, Z., Satybaldin, A., \& Koshanov, A. (2019). Methodology for Assessing the State of Human Capital in the Context of Innovative Development of the Economy: A ThreeLevel Approach. Journal of Asian Finance, Economics and Business, 6(1), 321-328. https://doi.org/10.13106/jafeb.2019. vol6.no1.321

Dahliah, D., Kurniawan, A., \& Putra, A. (2020). Analysis and Strategy of Economic Development Policy for SMEs in Indonesia. Journal of Asian Finance, Economics and Business, 7(5), 103-110. https://doi.org/10.13106/jafeb.2020.vol7. no5.103

De Vecchi, N. (1995). Entrepreneurs, Institutions and Economic Change: The economics thought of J.A. Schumpeter (19051925). London: Edward Elgar. https://doi.org/10.1111/ aehr.362br14

Dickey, A., \& Fuller, A. (1979). Distribution of the estimators for autoregressive time series with a unit root. Journal of the American Statistical Association, 74(366), 427-431. Available at: https://www.jstor.org/stable/2286348

Esguerra, H. (2009). Choosing and Assessing Local Youth Unemployment Interventions. ILO Working Paper, December 2009. Retrieved November 10, 2019, from: http://ilo.org/ wcmsp5/ groups/public/---asia /---ro-bangkok/---ilo-manila/ documents/publication/wcms_142950.pdf

Evangelista, G., \& Ortiz, A. (2009). Assessment of Training Policies of CHED, TESDA and Industry to Address Employment Mismatch. ILO Technical Report. DOI: 10.13140/ RG.2.1.2038.8880.

Evans, S., \& Leighton, S. (1990). Small business formation by unemployed and employed workers. Small Business Economics, 2(4), 319-330. https://www.jstor.org/stable/40228659

Gozun, C., \& Rivera, R. (2017). Role of Education in Encouraging Youth Employment and Entrepreneurship. DLSU Business \& Economics Review, 27(1), 72-88. Available at: https://www. dlsu.edu.ph/wp-content/uploads/2019/03/4gozun-072617.pdf 
Haftendorn, K., \& Salzano, C. (2004). Facilitating youth entrepreneurship: An analysis of awareness and promotion programmes in formal and non-formal education. SEED Working Paper No. 59. Geneva, Switzerland: International Labour Organization.

Hayton, C., George, G., \& Zahra, A. (2002). National culture and entrepreneurship. A review of Behavioral Research in Entrepreneurship Theory and Practice, 26(4), 33-52.

Herbig, P. A., \& Miller, J.C. (1992). Culture and technology: Does the traffic move in both directions? Journal of Global Marketing, 6, 75-104.

Johansen, S. (1988). Statistical Analysis of cointegration vectors. Journal of Economic Dynamics and Control, 12, 231-254. https://doi.org/10.1016/0165-1889(88)90041-3

Johansen, S., \& Juselius, K. (1990). Maximum likelihood estimation and inference on cointegration - with application to the demand for money. Oxford Bulletin of Economics and Statistics, 52(2), 169-210.

Kurozumi, E., \& Hayakawa, K. (2009). Asymptotic properties of the efficient estimators for cointegrating regression models with serially dependent errors. Journal of Econometrics, 149(2), 118-135. https://doi.org/10.1016/j.jeconom.2008.11.003

Lee, W., \& Kim, B. (2019). The Effects of Career Orientations on Entrepreneurial Satisfaction and Business Sustainability Journal of Asian Finance, Economics and Business, 6(4), 235248. https://doi.org/10.13106/jafeb.2019.vol6.no4.235

Leve, S., \& Kapingura, M. (2019). Influence of Perceived Time and Entrepreneurial Skills Constraints on Entrepreneurship Interest among Final Year Undergraduate and Honours Students at the University of Fort Hare. Journal of Reviews on Global Economics, 8(Special Issue), 1466-1474. https://doi. org/10.6000/1929-7092.2019.08.128

Manuelli, R. (2000). Technological Change, the Labor Market, and the Stock Market. NBER Working Paper 8022. https://www. nber.org/papers/w8022

Masih, R., \& Masih,A. (1996). Stock-Watson dynamic OLS (DOLS) and error-correction modelling approaches to estimating longand short-run elasticities in a demand function: New evidence and methodological implications from an application to the demand for coal in mainland China. Energy Economics, 18, 315-334. https://doi.org/10.1016/S0140-9883(96)00016-3

Mortensen, D., \& Pissarides, A. (1994). Job Creation and Job Destruction in the Theory of Unemployment. The Review of Economic Studies, 61(3), 397-415.

Nalubega, T., Kasumba, D. C., \& Uwizeyimana, D. E. (2019). Effects of Outsourcing on Employment Generation: Evidence from the Telecommunications Sector of Uganda. Journal of Reviews on Global Economics, 8, 1143-1156. https://doi. org/10.6000/1929-7092.2019.08.99

O'Higgins, N. (2003). Trends in the Youth Labour Market in Developing and Transition Countries. A Paper Prepared for the Youth Employment Workshop. The World Bank, Washington D.C. Retrieved January 17, 2020, from:: http://citeseerx.ist.psu.edu/viewdoc/download? doi $=10.1 .1 .501 .5811 \&$ rep $=$ rep $1 \&$ type $=$ pdf
Pernia, E., \& Herrin, A. (2003). Population, Human Resources and Unemployment in Balisacan and Hill's Philippine Economy: Development, Policies and Challenges. Oxford, UK: Oxford University Press. https://doi.org/10.1093/0195158989.003.00 09

Pesaran, M., Shin, Y., \& Smith, J. (2001). Bounds testing approaches to the analysis of level relationship. Journal of Applied Econometrics, 16, 289-326. https://doi.org/10.1002/ jae.616

Phillips, C. B., \& Perron, P. (1988). Testing for a unit root in time series regression. Biometrika, 75(2), 335-346. https://www. jstor.org/stable/2336182

Sanyal, S., Hisam, M., \& Baawain, A. (2020). Challenges Facing Internationalization of SMEs in Emerging Economies: A Study on OECD Model. Journal of Asian Finance, Economics and Business, 7(2), 281-289. https://doi.org/10.13106/jafeb.2020. vol7.no2.281

Satpayeva, Z., Kireyeva, A., Kenzhegulova, G., \& Yermekbayeva, D. (2020). Gender Equality and Women Business of Framework 5Ms in Kazakhstan: Analysis and Basic Directions. Journal of Asian Finance, Economics and Business, 7(3), 253-263. https:// doi.org/10.13106/jafeb.2020.vol7.no3.253

Schumpeter, A. (1934). The Theory of Economic Development. Cambridge: Harvard University Press.

Šileika, A., Rupšys, V., \& Gruževskis, B. (2004). Youth unemployment and its reduction measures. Journal of Business Economics and Management, 5(3), 119-131. https://doi.org/10. 1080/16111699.2004.9636076

Storey, D. J. (1991). The Birth of New Firms - Does Unemployment Matter? A Review of the Evidence. Small Business Economics, 3(3), 167-178. https://www.jstor.org/ stable/40228720

Sum, V. (2013). Unemployment, Consumer Confidence, Business Confidence, Inflation and Monetary Policy. SSRN Electronic Journal. DOI: 10.2139/ssrn.2146497

Sy, R. (2013). Youth Unemployment in the Philippines. Bureau of Local Employment, Department of Labor and Employment. Retrieved January 8, 2020, from: https://pdfs.semanticscholar. org/2cb1/2e10227f55ae050c43ff2933bda064c58ab2. pdf?_ga=2.216090770.564311365.1581471371 300363891.1581471371

Thurik, A. (2008). Entreprenomics: Entrepreneurship, economic growth and policy. In: Z.J. Acs, D.B. Audretsch \& R. Strom (eds.), Entrepreneurship, Growth and Public Policy. Cambridge, UK: Cambridge University Press. Retrieved January 17, 2020, from: https://papers.ssrn.com/sol3/papers. cfm?abstract_id=1276618

Thurik, A., Carree, A., van Stel, A., \& Audretsch, B. (2007). Does entrepreneurship reduce unemployment? Discussion Papers on Entrepreneurship, Growth and Public Policy. Retrieved November 17, 2020, from: https://www.econstor.eu/bitstream/ 10419/85927/1/01074.pdf

Trehan, B. (2001). Unemployment and Productivity. Economic Letter, Federal Reserve Bank of San Francisco, 28(12), 1-3. Retrieved February 17, 2020, from: https://www.frbsf.org/ economic-research/files/el2001-28.pdf 